Session ???? (paper - 2003-369)

\title{
Preparing College Students to Teach an Environmental Problem Solving Curriculum to Middle School Students
}

\author{
Susan E. Powers, Ph.D., P.E. \\ Center for the Environment, Clarkson University, \\ Potsdam NY 13699-5715 \\ PN: 315-268-6542; FN: 315-268-7985; sep@clarkson.edu
}

\begin{abstract}
An NSF-funded project-based program was implemented by Clarkson University in 2000 to increase the interest and knowledge of middle school students in science, math and technology through the solution of an environmental problem that is relevant to their local school community. Clarkson students developed curricula for $7^{\text {th }}$ and $8^{\text {th }}$ grade science and technology classes and then worked with the middle school students throughout the year to reduce to transform solid waste into valuable products. The solutions to this problem - food waste to compost and non-biodegradable waste as aggregates in concrete - provided a vehicle to teach fundamental science and math content as well as the process of doing science and solving problems.
\end{abstract}

Placing college science and engineering students in the classroom proved to be a great mechanism for engaging students in science topics and providing mentoring experiences that differ greatly from those that a practicing professional can provide. It is clear, however, that the students must be well prepared for this experience to maximize the benefits of university school district partnership programs. The objective of this paper is to describe the training program that has been developed to prepare Clarkson students to work effectively in middle school classrooms.

The Clarkson students are trained for their classroom experiences during the summer before they enter the classroom. They receive three credits for the training, curriculum development, and teaching efforts. It is expected that the students have the necessary background in science and technology to teach themselves the content and environmental relevance of the problem they will be teaching. Lectures and workshops focus on how to transform this knowledge into a projectbased curriculum that meets the needs of the teachers, while also exciting the students.

Lecture/workshops include: team work; components of an effective class and teacher; project planning and management; problem solving process; inquiry based learning, deductive/inductive learning; creating unit/lesson plan; defining learning objectives; incorporating mentoring into program; NYS standards and science exam; and, assessment techniques. Journals are used to encourage the fellows to reflect on their learning and own educational experiences. An evaluation of the program by both Clarkson students and their partner teachers indicated that this training was appropriate for the students to enter the classroom as professional scientists and engineers. Additional details about this program are available at http://www.clarkson.edu/k12. 
Overview of the Program

Through Clarkson's Project-Based Learning Partnerships, new curricula for middle school science and technology classes have been developed to expose middle school students to the societal impacts and mitigation of environmental problems. The concept of project-based learning incorporates a "big-picture" approach to enhancing science, math and technology knowledge, critical thinking, and problem solving skills. Project-based learning requires students to understand a problem, with all of the fundamental science, societal, ethical and other constraints, prior to assessing and implementing a solution.

The goal of Clarkson's Project-Based Learning Partnership program is to provide training to K12 Fellows who can then enhance the teaching of science and technology classes in area school districts. Because of this primary goal, the K-12 student will have an increased interest and appreciation for these subjects and improved critical thinking skills. The following objectives were defined to achieve its goals:

- Train graduate and advanced undergraduate student fellows in teaching and communication skills, and project-based learning approaches;

- Prepare college students to deliver science, math and technology concepts by effectively using hands-on activities in the classroom;

- Engage K-12 students via active learning through project-based learning as a means to enhance their interest and competency in science, math and technology concepts;

- Work in collaboration with area schoolteachers and administrators to establish these curricula in to meet local needs;

Real world problem solving involves an understanding of the complex interaction among various fundamental sciences, environmental, social, economic and ethical issues as well as computationally based analysis and design. Teaching students to think in a manner that would encompass these issues is needed at all levels of education. Therefore, the holistic approach we use in the classroom addresses projects that mirror the problem-solving techniques used by practicing engineers and scientists. These include:

- Problem identification and understanding

- Identifying alternatives to solve the problem

- Feasibility assessment leading to a proposed solution

- Implementation of the solution

- Evaluation of the success of the solution

Basic professional skills - oral and written communication skills, teaming skills, research (gathering information) skills, drawing conclusion, and decision making process are also necessary components of the project-based curriculum. The solution of this problem provides a vehicle for teaching fundamental science, math and technology classes in a relevant manner.

Project-based curricula that emphasize environmental problem solving skills have been developed for $7^{\text {th }}$ and $8^{\text {th }}$ grade science and technology classes. In New York State, the $7^{\text {th }}$ grade science class focuses on life sciences while the $8^{\text {th }}$ grade curriculum focuses on physical science. 
The development of the curricula required many compromises. Our program emphasized the process of doing science, whereas the textbook and the majority of the state science exam require knowledge of specific science content. Thus, it was critically important that our program fits the needs and covers content required within the state mandated core curricula. In each curriculum, we took a problem solving approach. For the middle school level, we broke the problem solving approach into four basic steps as illustrated in Figure 1.



Figure 1: Year-long problem solving process used in the Clarkson Project-Based Learning Partnership Program

At the beginning of the year, the students were posed with a problem statement: Too much solid waste generated in the school cafeteria is sent to a landfill. Wording of the problem we posed was critical in order to guide the students in the direction we wanted to go. Composting became an obvious solution for biodegradable wastes, while non-biodegradable materials were incorporated into concrete. These solutions provided the students with an understanding that they can reduce solid waste, as well as providing a topic that can be integrated into their required core curriculum. Over the course of the year, the students learned about solid waste, the science of composting and concrete, built and used compost bins, and tested the quality of the compost and concrete they generated. Throughout the year, the lessons focused both on solving the problem and on learning the math, science and technology required to solve this problem. 
Inquiry-based lessons and other active learning modes were used whenever appropriate. The teachers' needs, NYS standards, $7^{\text {th }}$ and $8^{\text {th }}$ grade textbooks, and new NYS $8^{\text {th }}$ grade science exam were all used as guides and constraints for the development of each lesson.

\section{Training Engineering Students for their Classroom Role}

Clarkson has used highly qualified graduate and advanced undergraduate students to bring the environmental problem-solving curriculum to middle school classrooms. The college students referred to here as "Fellows", are responsible for the lesson plan, materials and classroom teaching 2-3 days per week. The partner teacher is always present to help with discipline matters and to help relate our curriculum to other material the teacher covers in the classroom. The fellows are expected to be professionals in the classroom, not proficient teachers. Regardless, they need to understand how to engage the students in the lesson and communicate at an ageappropriate level.

A required three-credit class is offered to new Fellows during the summer preceding their teaching experience. The contents of the class, which have been refined over the last three years, have been developed based on input from education professors, our partner teachers, and our own experience with the strengths and weaknesses of the Fellows in the classroom. Table 1 identifies the topical areas covered in the class. In general, the workshops were all interactive, with a combination of lecture, discussion, group wok and presentations. For the most part, it is assumed that the Fellows have the required content knowledge to teach science and technology classes at the middle school level. A focused problem solving approach, which is integrated throughout the curriculum, is the primary content area that we review with the Fellows.

The expectations of Fellows in this class are clearly different than in other engineering classes. The course objectives for the Fellows include:

- To improved the students' communication and teaching skills

- To gain real life experience in project planning, teamwork, leadership.

- To learn to work in a true multidisciplinary environment.

- To learn the value of community service and professional stewardship

- To learn and then teach a holistic, project-based learning approach to problem solving

- To gain an appreciation for the relevance and usefulness of science and engineering within a larger social, political and economic context.

Assessing whether we have achieved these objectives is often difficult. Journal assignments have been very useful for addressing several of these components. Peer review and focus group discussions are also used.

A semester project, which is expected of each student in the class, contributes the greatest percentage of the student's grade (Table 2). This project has varied as the curriculum has been developed. Examples include developing and testing one laboratory activity at a college level to ensure success and then adapt that activity and write instructions for a middle school student, and writing unit and lesson plans for one component of the curriculum. 
Table 1: Primary workshop topics included in the three-credit class

\begin{tabular}{|c|c|c|}
\hline Topical Area & Key Concepts & Resource Materials \\
\hline $\begin{array}{l}\text { Overview of solid waste } \\
\text { problems and solutions }\end{array}$ & $\begin{array}{l}\text { Magnitude of solid waste disposal } \\
\text { Nature of wastes that are disposed }\end{array}$ & $\begin{array}{l}\text { U.S. EPA web site: } \\
\text { http://www.epa.gov/epaoswe } \\
\text { r/non-hw/muncpl/index.htm }\end{array}$ \\
\hline $\begin{array}{l}\text { Problem solving and } \\
\text { problem based learning }\end{array}$ & $\begin{array}{l}\text { Logical approach required to solve } \\
\text { any type of problem }\end{array}$ & $\begin{array}{l}\text { Woods }{ }^{1} \text { Chap. } 3 \\
\text { Wanakat and Oreovicz }{ }^{2} \\
\text { Chap. } 5 \\
\text { IMAST web site } \\
\text { www.ilstu.edu/depts/cemast }\end{array}$ \\
\hline $\begin{array}{l}\text { Scientific inquiry and } \\
\text { inquiry-based learning }\end{array}$ & $\begin{array}{l}\text { Scientific method } \\
\text { Science as a body of knowledge } \\
\text { versus a way of thinking } \\
\text { Science BY inquiry vs. science AS } \\
\text { inquiry }\end{array}$ & $\begin{array}{l}\text { Chiapetta et al. }{ }^{3} \text { Chaps. 1, } 5 \\
\text { NRC }^{4}\end{array}$ \\
\hline $\begin{array}{l}\text { Elements of an effective } \\
\text { class }\end{array}$ & $\begin{array}{l}\text { Events of instruction } \\
\text { Lewis learning styles inventory } \\
\text { Variety is important } \\
\text { Leading discussion classes vs. } \\
\quad \text { lecture }\end{array}$ & $\begin{array}{l}\text { Borich }^{5} \text { pp. } 136-146 \\
\text { Chiappetta et al. }{ }^{3} \\
\text { Chap. } 5\end{array}$ \\
\hline Unit and lesson plans & $\begin{array}{l}\text { Planning a class is essential } \\
\text { Elements of a unit plan } \\
\text { Elements of a Lesson Plan } \\
\text { Defining learning objectives } \\
\text { Concept maps as an organization } \\
\text { tool }\end{array}$ & $\begin{array}{l}\text { Chiappetta et al. }{ }^{3} \\
\text { Chaps. } 12-13\end{array}$ \\
\hline $\begin{array}{l}\text { Choosing course content } \\
\text { and appropriate level for } \\
\text { communication }\end{array}$ & $\begin{array}{c}\text { Compliance with NYS and } \\
\text { national standards }\end{array}$ & $\begin{array}{l}\text { Chiapetta et al. }{ }^{3} \text { Chap. } 2 \\
\text { Wagner and Fiero }{ }^{6} \\
\text { NYS Standards: } \\
\text { http://www.emsc.nysed.gov/ } \\
\text { ciai/pub.html\#cat4 } \\
\text { NRC }^{4}\end{array}$ \\
\hline Project planning & $\begin{array}{l}\text { Defining objectives for a project } \\
\text { Defining tasks and timelines for } \\
\text { work }\end{array}$ & Lewis $^{7}$ pp. 16-23, 30-35 \\
\hline $\begin{array}{c}\text { Classroom climate and } \\
\text { discipline }\end{array}$ & Rules of the classroom & $\begin{array}{l}\text { Panel discussion with partner } \\
\text { teachers }\end{array}$ \\
\hline Assessment of learning & $\begin{array}{l}\text { Bloom's taxomony of learning } \\
\text { Types of exam questions to } \\
\text { address all Blooms levels } \\
\text { Other assessment techniques }\end{array}$ & $\begin{array}{l}\text { Chiapetta et al. }{ }^{3} \text { Chap. } 14 \\
\text { Wagner and Fiero }{ }^{6} \\
\text { NYS Standards: } \\
\text { http://www.emsc.nysed.gov } \\
\text { /ciai/pub.html\#cat4 }\end{array}$ \\
\hline
\end{tabular}


The quality of teaching is assessed during summertime practice teaching sessions as well as throughout the school year. A rubric was developed for this program for assessing the classroom skills. An early version of this rubric, which would be appropriate for a student teacher, was deemed not appropriate for the Fellows after one semester. The current version shows the expectation of good communication skills in the classroom. It is now geared more for a professional scientist or engineer in the classroom.

Table 2: Grading System

$\begin{array}{ll}\text { journal assignments } & 15 \% \\ \text { semester project } & 30 \% \\ \text { contributions to class discussion } & 15 \% \\ \text { preparedness for class and team meetings } & 15 \% \\ \text { quality and/or improvement in teaching skills } & 15 \% \\ \text { quality and improvement in team work } & 10 \%\end{array}$

\section{Outcomes Assessment}

Assessment of the outcomes of this program has been completed by Dr. Timothy Schwob, from the Center for Rural Education at SUNY Potsdam. One component of this assessment has been the development, implementation and analysis of class observation form mentioned above. Some key findings from the AY02 assessment report include:

- The FELLOWS appear to exhibit strength in organization, anticipatory set, and questioning skills.

- Verbal interaction is cited as a particular strength of the FELLOWS.

- The content knowledge of the FELLOWS is strong.

- Their style of lesson delivery-a good mix of teacher-directed and student group work-is excellent.

- In general, the FELLOWS are rated quite highly for their delivery of information in an interesting and clear way.

- Ending a lesson with sufficient time for a summary continues to be a problem for the FELLOWS. This is one area that seems to need additional reinforcement for the FELLOWS.

- The lesson and unit planning of the FELLOWS is highly rated by the TEACHERS with lessons and units being age-appropriate, addressing local and state curricula, containing clear and attainable objectives, and providing a wide variety of learning strategies.

The success of the Fellows' classroom time is an indication that the training they receive in the three-credit class and the time they spend preparing classroom materials has also been successful.

\section{Acknowledgements}

Funding for this program was provided by the National Science Foundation through their GK-12 program (DUE 9979509). The opportunity NSF has provided to initiate this program is gratefully acknowledged. 


\section{Bibliography}

1. Woods, D.R. 1994. Problem-Based Learning: How to Gain the Most from PBL, Woods, Waterdown ON.

2. Wankat, P.C., F.S. Oreovicz, 1993. Teaching Engineering, McGraw Hill, New York.

3. Chiapetta, E.L., T.R. Koballa, Jr., A.T. Collette, 1998. Science Instruction in the Middle and Secondary Schools, $4^{\text {th }}$ ed., Merrill/Prentice Hall, Upper Saddle River NJ.

4. National Research Council, 1996. National Science Education Standards, National Academy Press, Washington DC.

5. Borich, G.D., 2000. Effective Teaching Methods, $4^{\text {th }}$ ed., Merrill/Prentice Hall, Upper Saddle River NJ.

6. Wagner, J. and Fiero, A., 2001. Science Big 8 Review, N\&N Publishing Company, Middletown NY.

7. Lewis, J.P., 1997. Fundamentals of Project Management” AMACON, New York.

\section{Biographical Information}

SUSAN E. POWERS, Ph.D., P.E., is the Director of the Center for the Environment and a Professor in the Department of Civil and Environmental Engineering at Clarkson University. Her involvement with K-12 outreach stems from project-based work at the college level and her interest in better preparing and exciting young students for engineering education. 